\title{
Multiple Roles of Bone Morphogenetic Protein Signaling in the Regulation of Cortical Cell Number and Phenotype
}

\author{
Peter C. Mabie, Mark F. Mehler, and John A. Kessler \\ Departments of Neurology and Neuroscience and the R. F. Kennedy Center for Research in Mental Retardation and \\ Human Development, Albert Einstein College of Medicine, Bronx, New York 10461
}

\begin{abstract}
Members of the bone morphogenetic protein (BMP) family have been implicated in multiple aspects of neural development in both the CNS and peripheral nervous system. BMP ligands and receptors, as well as the BMP antagonist noggin, are expressed in the developing cerebral cortex, making the BMPs likely candidates for regulating cortical development. To define the role of these factors in the developing cerebral cortex, we examined the effects of BMP2 and BMP4 on cortical cells in vitro. Cells were cultured from embryonic day 13 (E13) and E16 rat cerebral cortex in the absence or presence of different concentrations of fibroblast growth factor 2, a known regulator of cortical cell proliferation and differentiation. At E13, the BMPs promoted cell death and inhibited proliferation of cortical ventricular zone cells, resulting in the generation of fewer neurons and no glia. At E16, the effects of the BMPs were more com-
\end{abstract}

plex. Concentrations of BMP2 in the range of $1-10 \mathrm{ng} / \mathrm{ml}$ promoted neuronal and astroglial differentiation and inhibited oligodendroglial differentiation, whereas $100 \mathrm{ng} / \mathrm{ml} \mathrm{BMP2}$ promoted cell death and inhibited proliferation. Addition of the BMP antagonist noggin promoted oligodendrogliogenesis in vitro, demonstrating that endogenous BMP signaling influences the differentiation of cortical cells in vitro. The distribution of BMP2 and noggin within the developing cortex suggests that local concentrations of ligands and antagonists define gradients of BMP signaling during corticogenesis. Together, these results support the hypothesis that the BMPs and their antagonist noggin co-regulate cortical cell fate and morphogenesis.

Key words: bone morphogenetic protein; embryogenesis; fibroblast growth factor; gliogenesis; neurogenesis; noggin; subventricular zone; ventricular zone
All of the major cellular elements of the brain arise from specialized generative zones, the ventricular and subventricular zones (VZ/SVZ), that are derived from the pseudostratified neuroepithelium of the neural tube (Altman and Bayer, 1995). The mechanisms that regulate neuroepithelial cell diversification and the appropriately timed differentiation of neurons and glia during corticogenesis are poorly understood. Although there is clearly heterogeneity among the VZ/SVZ populations of cells, substantial evidence indicates that a proportion of these cells are multipotential, i.e., they can generate all phenotypes depending on the cellular microenvironment (Reynolds and Weiss, 1992; Reynolds et al., 1992; Kilpatrick and Bartlett, 1993; Davis and Temple, 1994; Williams and Price, 1995; Johe et al., 1996; for review, see Stemple and Mahanthappa, 1997). Although these cells have the potential to generate these different neural phenotypes throughout development, neurons, radial glia, astrocytes, and oligodendroglia are primarily generated in different temporospatial waves during the embryonic and postnatal periods. This may reflect changes in the factors to which progenitor cells are exposed at various stages of development, changes in the properties of these cells during ontogeny, or both. Further complicating our understanding of lineage development within the cortex, there is now

Received Oct. 30, 1998; revised June 1, 1999; accepted June 4, 1999.

This work was supported by grants from the National Institutes of Health (P.C.M., M.F.M., and J.A.K.). We thank Anthony Celeste, John Wozney, and Genetics Institute for providing us with BMPs 2 and 4 and the monoclonal antibody to BMP2. We thank Aris Economides, George Yancopoulos, and Regeneron Pharmaceuticals for providing us with noggin and anti-noggin antibodies.

Correspondence should be addressed to Dr. Peter C. Mabie, Department of Neurology, Albert Einstein College of Medicine, Kennedy Center, Room 401, 1300 Morris Park Avenue, Bronx, NY 10461.

Copyright (C) 1999 Society for Neuroscience 0270-6474/99/197077-12\$05.00/0 increasing recognition that apoptosis is a prominent and highly regulated event during corticogenesis (Finlay and Slattery, 1983; Ferrer et al., 1992; Wood et al., 1992; Blaschke et al., 1996; Takahashi et al., 1996a,b; Furuta et al., 1997; Price et al., 1997). Consequently, selective survival of different populations of progenitor cells may be important not only for the timely specification of cellular phenotypes but also for the morphogenesis of the brain.

There is increasing evidence that multiple classes of extracellular signals regulate the proliferation and differentiation of neural progenitor cells. Mitogenic factors for neural progenitors include fibroblast growth factor 2 (FGF2) and epidermal growth factor (EGF). FGF2 regulates the proliferation of cortical VZ progenitor cells (Murphy et al., 1990; Kilpatrick and Bartlett, 1995; Johe et al., 1996) and progenitor cells that persist in the subependymal zone into adulthood (Gritti et al., 1996). In addition, FGF2 regulates the fate of $\mathrm{VZ}$ progenitor cells in vitro, with low concentrations favoring neuronal differentiation, higher threshold concentrations favoring oligodendroglial differentiation, and additional environmental factors required for astrocytic differentiation (Qian et al., 1997). In contrast to the proliferative effect of FGF2 on early VZ progenitor cells, EGF is a potent mitogen for later multipotent progenitor cells from the embryonic and adult SVZ (Reynolds and Weiss, 1992; Reynolds et al., 1992).

Increasing evidence suggests that the fate of neural progenitors is regulated by members of the bone morphogenetic protein (BMP) subclass of the TGF $\beta$ superfamily. The BMPs have multiple functions in embryogenesis and in neural development. In addition to their complex roles in the development of neural crest and the peripheral nervous system (Fann and Patterson, 1994; Liem et al., 1995; Lien et al., 1995; Sasai et al., 1995; Wilson and 
Hemmati-Brivanlou, 1995; Mujtaba et al., 1998), they promote the differentiation of neuronal precursors in the spinal cord (Kalyani et al., 1998) and cortex (Li et al., 1998) and promote astroglial lineage commitment by forebrain SVZ progenitor cells (Gross et al., 1996). In certain contexts, the BMPs also induce apoptosis of neural cells (Graham et al., 1994; Glozak and Rogers, 1996; Song et al., 1998), including early telencephalic neuroectoderm (Furuta et al., 1997). BMPs and their receptors are abundantly expressed in the brain from early embryogenesis throughout adult life (Furuta et al., 1997; Mehler et al., 1997; Zhang et al., 1998). BMP actions are regulated in vivo by proteins such as noggin, chordin, and follistatin, which antagonize BMP signaling by directly binding BMPs and blocking ligand activity (for review, see Cho and Blitz, 1998). In addition, in many contexts, the effects of the BMPs are opposed by other growth factors, such as EGF and FGFs, which are thought to interfere with the intracellular BMP signaling pathway (Bernier and Goltzman, 1992; Niswander and Martin, 1993; Ganan et al., 1996; Kretzschmar et al., 1997; Neubuser et al., 1997).

These observations collectively suggest that the BMPs play a fundamental role in many aspects of embryogenesis of the nervous system. The precise actions of this family of proteins at different stages of ontogeny, in particular the relationship between the promotion of apoptosis and differentiation, however, remain unclear. Our results demonstrate that the BMPs have complex effects on the survival and differentiation of developing cortical cells. At embryonic day 13 (E13), at approximately the onset of cortical neurogenesis, high concentrations of the BMPs (10-100 $\mathrm{ng} / \mathrm{ml})$ promote apoptotic death and inhibit the proliferation of cultured $\mathrm{VZ}$ progenitor cells, resulting in a decrease in the generation of both neurons and glia. In identical culture conditions at E16, near the midpoint of neurogenesis, moderate concentrations of the BMPs $(1-10 \mathrm{ng} / \mathrm{ml})$ promote neuronal differentiation, and to a lesser extent astrocytic differentiation, while completely preventing the development of oligodendroglia. These observations demonstrate that BMP effects on CNS cells are context-specific and change during ontogeny.

\section{MATERIALS AND METHODS}

Cell cultures. Timed pregnant Sprague Dawley rats were killed by $\mathrm{CO}_{2}$ narcosis at either embryonic day 13 (E13) or E16 (counting the morning of the vaginal plug as day 1), and embryos were aseptically removed and placed in Puck's saline G. Dorsolateral cerebral cortex was dissected and enzymatically dissociated with trypsin $0.05 \%$ for 5 (E13) or 10 (E16) min, mixed with an equal volume of Neurobasal medium (Life Technologies, Gaithersburg, MD) supplemented with $10 \%$ fetal bovine serum, centrifuged at $700 \mathrm{rpm}$ for $5 \mathrm{~min}$, placed in serum-free medium (SFM), triturated, and then passed through a $20 \mu \mathrm{M}$ nytex filter. After counting viability by trypan blue exclusion, cells were plated in a volume of $10 \mu \mathrm{l}$ onto poly-D-lysine (PDL)-coated $(20 \mu \mathrm{g} / \mathrm{ml})$ Terasaki plates in SFM at low ( $\sim 10$ cells per well) or moderate ( $250-300$ cells per well) density. For some moderate density experiments, cells were plated in 24 -well plates at $2 \times 10^{4}$ cells per well. SFM consisted of Neurobasal medium supplemented with N2 and B27 (Life Technologies), L-glutamine (2 mM), penicillin $(100 \mathrm{U} / \mathrm{ml})$, and streptomycin $(100 \mu \mathrm{g} / \mathrm{ml})$. Cells were maintained in a humidified incubator at $37^{\circ} \mathrm{C}$ with $5 \% \mathrm{CO}_{2}$. An additional 5 $\mu \mathrm{l}$ of SFM was added to each well at 4-5 days in vitro (div). BMP2 and FGF2 were added only once at the time of plating, whereas noggin was readded with SFM at 4-5 div. For clonal analysis, three to four cells were plated per Terasaki well or 300-400 cells were plated onto PDL-coated $35 \mathrm{~mm}$ plates with gridded bottoms (Nunc, Naperville, IL), and individual viable cells were marked 1-2 hr later. Cultures were then maintained as described above for low-density cultures, with the exception that fibronectin $(1 \mu \mathrm{g} / \mathrm{ml})$ was added to the SFM at the time of plating.

Growth factors. Recombinant human BMPs 2 and 4 were provided by A. Celeste and J. Wozney of Genetics Institute (Cambridge, MA). Recombinant human noggin was provided by A. Economides and G.
Yancopoulos of Regeneron Pharmaceuticals (Tarrytown, NY). FGF2 was purchased from Collaborative Biomedical (Bedford, MA).

Immunocytochemistry. At the designated time, cells were fixed with cold methanol for $10 \mathrm{~min}$ and washed twice with PBS. For oligodendroglial (O4) staining, cells were incubated with O4 supernatant for $20 \mathrm{~min}$ at room temperature and rinsed with PBS before fixation. Primary antibodies diluted in PBS containing 5\% heat-inactivated goat serum were applied for 2-4 hr. After three washes with PBS, species- and isotype-specific fluoroscein and/or rhodamine-labeled secondary antibodies (Southern Biotechnology, Alabaster, AL) diluted 1:100 and containing $1 \mu \mathrm{g} / \mathrm{ml}$ bisbenzimide were applied at room temperature for $1 \mathrm{hr}$. Cell staining was visualized and photographed with an Olympus Opticals (Tokyo, Japan) fluorescent microscope. Primary antibodies (mouse monoclonals) used were anti- $\beta$ tubulin III (1:100-1:400, depending on lot; Sigma, St. Louis, MO), anti-glial fibrillary acidic protein (GFAP) (1:400; Sigma), anti-nestin (1:1000; PharMingen, San Diego, CA), and O4 (supernatant diluted 1:2-5 from the mouse hybridoma cell line; the gift of S. Pfeiffer, University of Connecticut). Some cultures were triplelabeled using a combination of fluorescent and biotin-avidin-peroxidase (Vector ABC kit; Vector Laboratories, Burlingame, CA) stains.

Immunohistochemistry. The brains of E16 rats and E15 and newborn mice were fixed by immersion in $0.5 \%$ zinc acetate, $0.5 \%$ zinc chloride, and $0.05 \%$ calcium acetate in $50 \mathrm{~mm}$ Tris, $\mathrm{pH} 7.2$ for $1-2 \mathrm{~d}$ (Beckstead, 1994). After cryoprotection in $30 \%$ sucrose in $50 \mathrm{~mm}$ Tris, tissue was frozen in isopentane, and $12 \mu \mathrm{m}$ cryosections were placed onto Superfrost Plus slides (Fisher Scientific, Houston, TX) and air-dried overnight. Sections were treated with $0.3 \% \mathrm{H}_{2} \mathrm{O}_{2}$ in methanol for $20 \mathrm{~min}$ to permeabilize membranes and quench endogenous peroxidase activity. Primary antibodies were applied for $2-4 \mathrm{hr}$, followed by fluorescent antibody (as above) or biotinylated secondary antibodies, ABC reagent, and the VIP substrate kit (Vector Laboratories) following the manufacturer's protocol. Primary antibodies used were a mouse monoclonal anti-BMP2 diluted 1:4000 (the gift of Genetics Institute), an affinitypurified goat polyclonal anti-BMP2 diluted 1:100 (Research Diagnostics, Flanders, NJ), and two different affinity purified rat monoclonal antinoggin antibodies (RP57-16 and RP57-21; gift of Regeneron Pharmaceuticals) diluted 1:500 and 1:100, respectively. Specificity of staining was demonstrated by the following criteria: (1) the absence of any detectable staining with several irrelevant monoclonal antibodies, (2) a correlation between intensity of immunoreactivity and the documented level of transcript expression in the same tissue by Northern blot (Valenzuela et al., 1995) or nuclease protection assay (Gross et al., 1996), and (3) an identical pattern of immunoreactivity using two different antibodies.

Quantification. The number of viable cells per Terasaki well was counted at sequential time points before fixation in at least 30 wells for low-density and 10 wells for moderate-density cultures. Morphological criteria for determining viability were the presence of an intact cell membrane and processes and the absence of significant cell shrinkage and/or formation of membrane-bound bodies under $20 \times$ phase microscopy. Nonviable cells consistently exhibited shrinkage of the soma to $<50 \%$ of the size of average cells in the same well, retraction and/or disintegration of processes, and nuclear pyknosis or the formation of membrane-bound (apoptotic) bodies containing nuclear fragments. With close serial inspection of low-density cultures, remnants of virtually all nonviable cells remained visible for several days, allowing for a precise assessment of proliferation and viability. In multiple experiments, a subset of wells were analyzed by trypan blue exclusion and/or bisbenzimide nuclear staining within $45 \mathrm{~min}$ of morphological assessment of viability, confirming the accuracy of the morphological criteria to within $2-3 \%$. Similar results were seen in at least three separate culture experiments. Results are expressed as the mean \pm SEM, with significance determined by the $t$ test.

\section{RESULTS}

To define the effects of the BMPs on cortical progenitor cell survival, proliferation, and differentiation, cortical cells from E13 and E16 rats were treated with the BMPs in several culture conditions: one that favors proliferation and subsequent differentiation of both neurons and glia (FGF2 $10 \mathrm{ng} / \mathrm{ml}$ ), one that favors more limited proliferation and subsequent neuronal differentiation (FGF2 $0.1 \mathrm{ng} / \mathrm{ml}$ ), and one that favors early neuronal differentiation (no FGF2) (Qian et al., 1997). Cultures grown at both moderate and low densities were also compared to help deter- 
mine whether BMP effects are influenced by autocrine-paracrine signaling.

\section{BMPs are negative regulators of cortical VZ cell number}

The first set of experiments examined rat E13 cortical cells plated at $\sim 10$ cells per Terasaki well in serum-free medium supplemented with FGF2 $10 \mathrm{ng} / \mathrm{ml}$. This concentration of FGF2 promotes the proliferation of multipotent $\mathrm{VZ}$ progenitor cells plated at low density and the generation of both neurons and glia (Qian et al., 1997). At the time of plating, $92 \pm 6 \%$ of E13 cortical cells expressed nestin, a marker for undifferentiated neuroepithelial cells. No cells expressed detectable astrocytic (GFAP) or O4 markers, but $16 \pm 5 \%$ expressed $\beta$ tubulin III, a neuronal marker (the small population of dual-immunoreactive cells presumably represents a transient developmental stage at the onset of neuronal differentiation). In the absence of FGF2, all cells died within $3 \mathrm{~d}$. In the presence of FGF2, there was extensive proliferation of nestin-immunoreactive cells and a significant increase in the number of $\beta$ tubulin III-immunoreactive neurons over 8 div (Figs. 1,2). When E13 cortical cells were grown with FGF2 plus increasing concentrations of BMP2, the number of cells generated was markedly decreased (Figs. 1, 2). The trend toward decreased cell numbers after BMP2 treatment was apparent within 2 div and reached statistical significance at 3 div. Serial cell counts of viable and nonviable cells revealed that BMP treatment increased the percentage of dying cells and decreased the rate of proliferation. Cell viability was quantified by morphological analysis and confirmed by trypan blue exclusion (see Materials and Methods). At 5 div, viability was $80 \pm 7 \%$ with FGF2, $62 \pm 6 \%$ with FGF2 plus BMP2 $10 \mathrm{ng} / \mathrm{ml}(p=0.021)$, and $42 \pm 7 \%$ with FGF2 plus BMP2 $100 \mathrm{ng} / \mathrm{ml}(p=0.0048)$. Dying cells typically displayed shrinkage of the soma with the formation of membrane-bound bodies under phase microscopy and pyknosis and/or fragmentation of the nucleus with bisbenzimide staining (Fig. 1), the morphological hallmarks of apoptosis (Kerr et al., 1995). Dying cells included both neurons (tubulin III-immunoreactive) and neuroepithelial cells (nestin-immunoreactive), without apparent selectivity.

Similar results were obtained when E13 cortical cells were plated at moderate density (Fig. 2). Trypan blue viability assays at sequential time points from 3 to 8 div demonstrated that BMP2 cotreatment increased the percentage of dead cells (data not shown). In addition, proliferation assays of moderate-density cultures demonstrated that $77 \pm 2 \%$ of cells treated with FGF2incorporated bromodeoxyuridine at 3 div compared with only $59 \pm 3 \%$ of cells cotreated with BMP2 $10 \mathrm{ng} / \mathrm{ml}(p=0.00048)$. A similar reduction in the percentage of cells expressing proliferating cell nuclear antigen (PCNA) was present at 6 div (data not shown). Thus, in both low-density and high-density cultures, the net decrease in cell number resulted from both increased cell death and decreased proliferation. At 8 div, BMP treatment decreased the numbers of both neurons ( $\beta$ tubulin IIIimmunoreactive) and undifferentiated neuroepithelial cells (nestin-immunoreactive), without changing their relative proportion (no differentiated glial cells were detected at this time). At 12 div, however, FGF2-treated cultures contained $20 \pm 4 \%$ oligodendrocytes (O4-immunoreactive) and $42 \pm 4 \%$ astrocytes (GFAP-immunoreactive). Differentiated glia were absent in cultures cotreated with BMP2 $10 \mathrm{ng} / \mathrm{ml}$. Thus, BMP treatment inhibited the net production of both neurons and glia. BMP4 had similar effects, except that its potency was somewhat greater than BMP2 at equivalent doses (data not shown).

To examine the effects of the BMPs in conditions that favor more restricted neuronal development, additional experiments were performed at moderate density in the absence or presence of lower doses of FGF2 $(0.1 \mathrm{ng} / \mathrm{ml})$. E13 cortical cells cultured at this dose of FGF2 exhibited less proliferation than cells grown in $10 \mathrm{ng} / \mathrm{ml} \mathrm{FGF} 2$, and $81 \pm 8 \%$ differentiated into neurons by 6 div. BMP2 $(10 \mathrm{ng} / \mathrm{ml})$ had two effects. First, BMP2 markedly decreased the number of cells generated (Fig. 2B). As with cultures grown in the higher dose of FGF2 $(10 \mathrm{ng} / \mathrm{ml})$, the reduction in cell number reflected increased cell death and decreased proliferation, and again, the proportion of neurons to undifferentiated cells was not significantly altered (data not shown).

E13 cortical cells cultured in the absence of FGF2 displayed limited proliferation, with $90 \pm 4 \%$ of cells differentiating into neurons within 4 div. Increasing doses of BMP2 dramatically decreased the viability of neurons (Fig. $2 C$ ). Thus, the BMPs negatively regulated E13 cortical cell number in conditions that both favored proliferation and fostered differentiation. Higher concentrations of BMP2 were required to significantly reduce cell numbers in the absence of FGF2, suggesting that the proliferative effect of FGF2 may sensitize E13 cortical cells to the deathinductive and anti-mitotic effects of the BMPs. In all of these conditions, those neurons that survived in the presence of the BMPs typically displayed more extensive neuritic outgrowth than control neurons (data not shown) (Li et al., 1998).

\section{Moderate doses of BMPs promote neuronal differentiation and inhibit oligodendroglial differentiation of E16 cortical cells}

Cultures of E16 cortical cells grown in serum-free medium plus FGF2 displayed several differences from E13 cells. As expected, a higher percentage of cells at the time of plating already expressed the neuronal marker $\beta$ tubulin III ( $35 \pm 4 \%$ for E16; $16 \pm$ $5 \%$ for E13), a lower percentage of cells expressed the neuroepithelial marker nestin ( $69 \pm 7 \%$ for E16; $92 \pm 6 \%$ for E13), and accordingly, fewer cells initially proliferated in response to FGF2. In addition, glial cells differentiated more quickly, reaching significant levels within 8 div (Figs. 3, 4B). In cultures plated at low density, many oligodendrocytes had differentiated by 8 div, whereas astrocytes rarely differentiated, even after 12 div. At moderate density, both oligodendrocytes and astrocytes were present by 8 div. The effects of BMP treatment on E16 cortical cells also significantly differed from E13 cells. First, concentrations of BMP2 in the $1-10 \mathrm{ng} / \mathrm{ml}$ range did not significantly alter total cell number in low-density cultures (Fig. 4A). However, the phenotype of the cells that developed was significantly altered. By 8 div, BMP treatment dramatically increased the percentage of neurons that developed and virtually abolished the generation of oligodendrocytes (Figs. 3, 4B). These effects occurred without altering the percentage of undifferentiated cells (Fig. 4B). Furthermore, there was no significant effect on viability or proliferation based on serial cell counts (Fig. $4 A$ ) and PCNA expression. At 3 div, PCNA was expressed by $84 \pm 4 \%$ of FGF-treated cells and by $82 \pm 5 \%$ of FGF2 plus BMP2-treated cells. PCNA was coexpressed by nestin-immunoreactive cells but never by $\beta$ tubulin III-immunoreactive cells; this suggests that the increase in neurons seen with BMP treatment reflected enhanced neuronal differentiation of neuroepithelial progenitor cells rather than proliferation of cells already expressing the neuronal phenotype.

To confirm these results, a clonal analysis was performed. Cells 

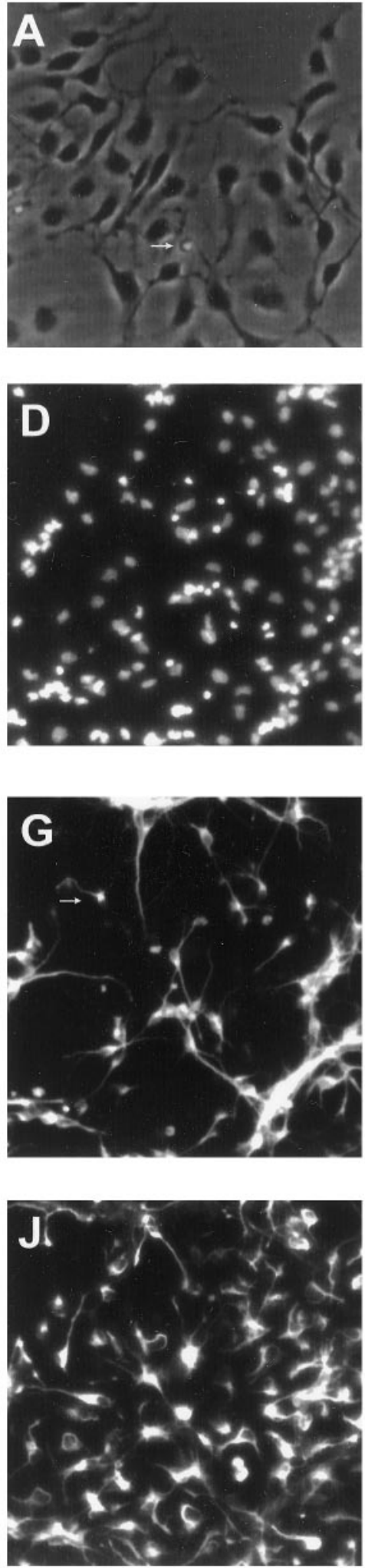
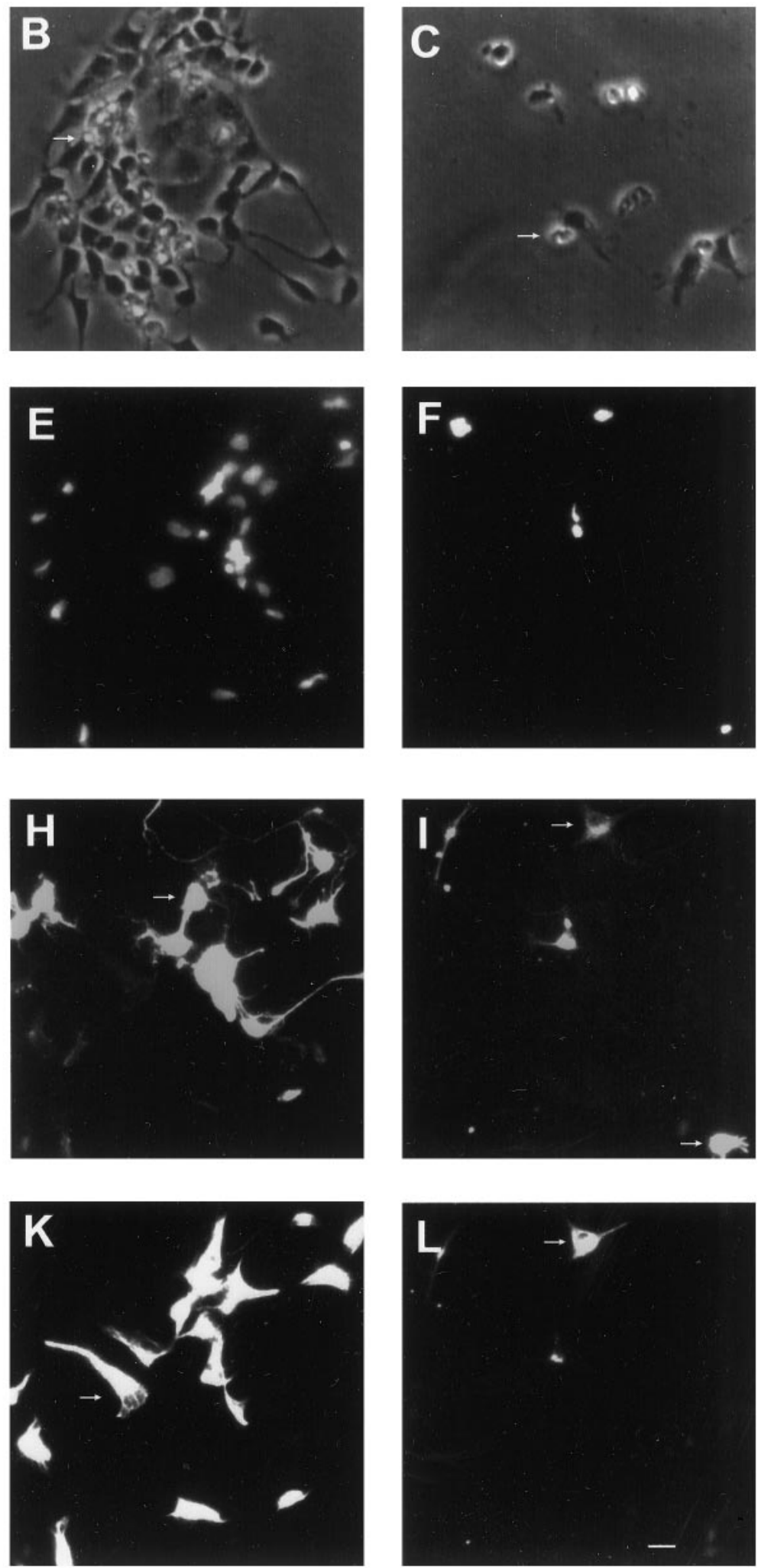

Figure 1. Effects of BMP2 on the growth of cortical VZ cells plated at low density with FGF2 $10 \mathrm{ng} / \mathrm{ml}$. Photomicrographs of rat E13 cortical cells grown with FGF2 alone $(A, D, G, J), \mathrm{FGF} 2$ plus BMP2 $10 \mathrm{ng} / \mathrm{ml}(B, E, H, K)$, or FGF2 plus BMP2 $100 \mathrm{ng} / \mathrm{ml}(C, F, I, L)$. $A-C$, Phase-contrast images at 5 div. $D-F$, Bisbenzimide staining at 8 div. $G-I, \beta$ tubulin III staining at 8 div. $J-L$, Nestin staining at 8 div. The same photographic field is shown for each condition in $D, G, J ; E, H, K$; and $F, I, L$ at 8 div. Arrows indicate examples of dying cells with apoptotic bodies $(A-C)$, cells expressing $\beta$ tubulin III-immunoreactivity $(G-I)$, and nestin immunoreactivity $(J-L)$. In each condition, an occasional cell coexpressed both $\beta$ tubulin III and nestin (for example, the top cell indicated with an arrow in $I$ and $L$ ). Scale bar: $A-C, 8 \mu \mathrm{M} ; D-L, 12 \mu \mathrm{M}$. 


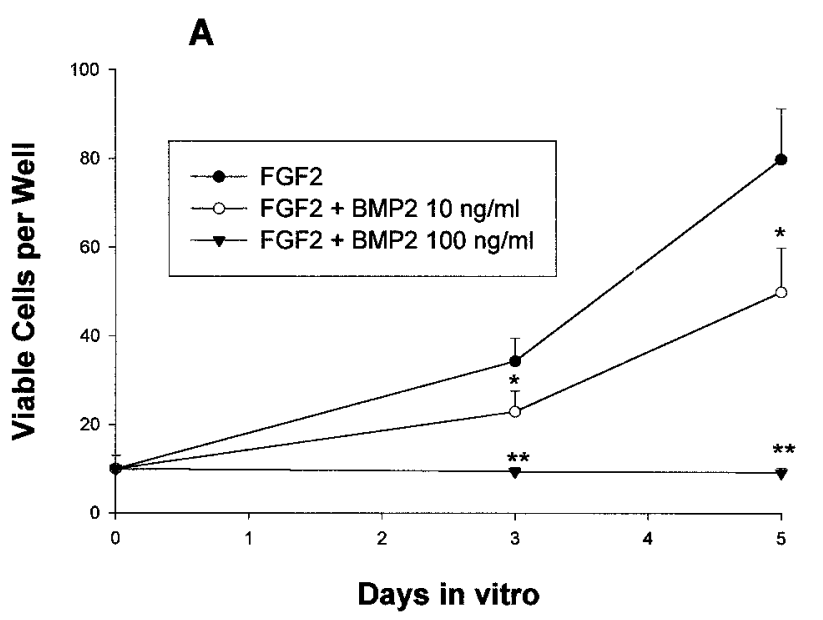

B
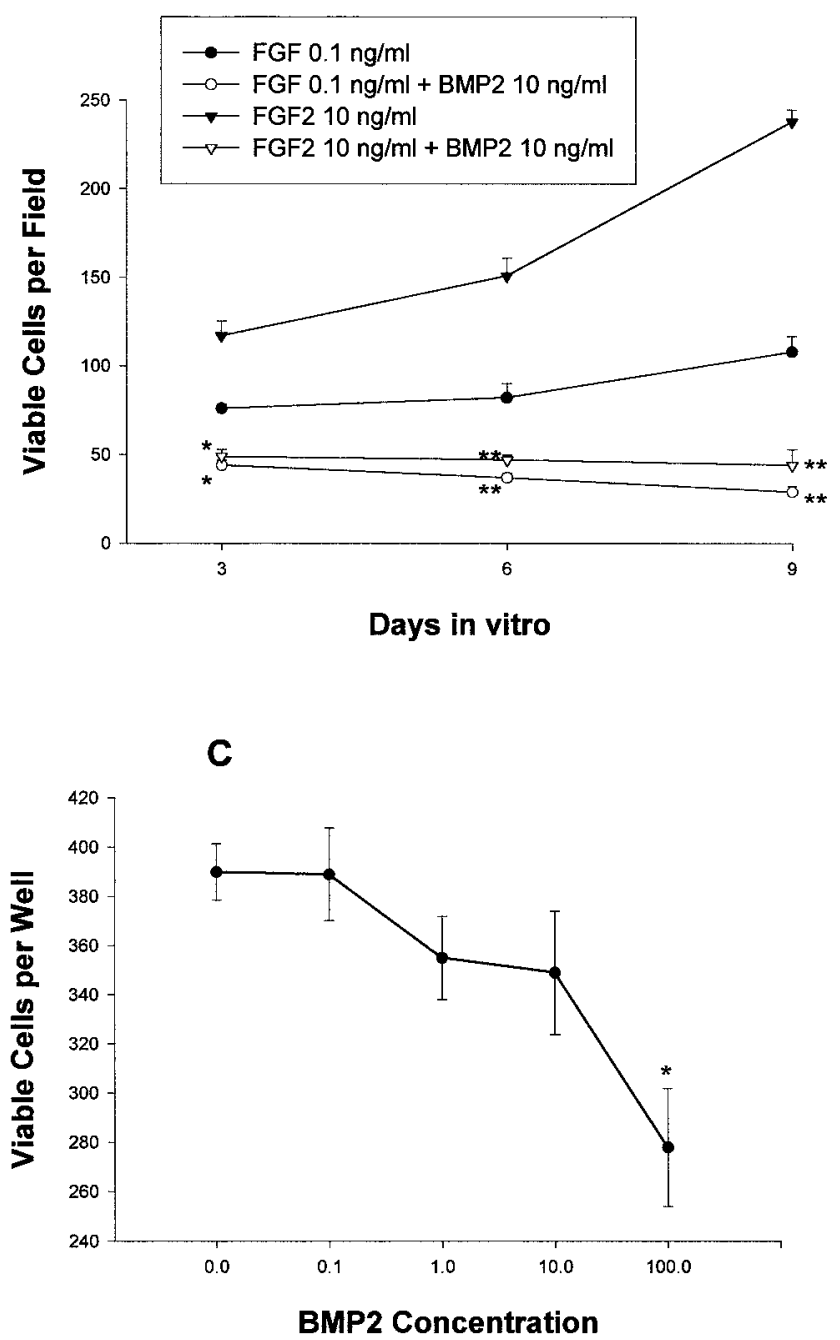

Figure 2. Effects of BMP2 on the growth of cortical VZ cells. The number of total viable cells was quantitated at the indicated time points. $A$, Effects of BMP2 10-100 ng/ml on E13 cells grown at low density with FGF2 $10 \mathrm{ng} / \mathrm{ml}$ for 8 div. $B$, Effects of BMP2 $10 \mathrm{ng} / \mathrm{ml}$ on cells grown at moderate density with FGF2 $0.1-10 \mathrm{ng} / \mathrm{ml}$ for 9 div. $C$, Effects of BMP2 $0.1-100 \mathrm{ng} / \mathrm{ml}$ on E13 cortical cells grown at moderate density without FGF2 for 5 div. * $p<0.05 ; * * p<0.01$. were plated at clonal density (see Materials and Methods), and the fate of individual cells was then followed for $8 \mathrm{~d}$ (Table 1). The rate of survival of single nondividing cells and cells that generated small (two to four cells) and large (more than four cells) clones was similar between FGF2 alone and FGF2 plus BMP2. Likewise, the phenotype of single cells and small clones was similar between the two groups. The large clones, however, differed in several respects. As predicted based on the low-density results above, large FGF2 plus BMP2-treated clones were more likely to contain neurons, and those that did contained a higher percentage of neurons than large FGF2-treated clones. Again, BMP2 completely inhibited the development of oligodendroglia. BMP2-treated clones tended to be smaller, reflecting decreased proliferation and slightly increased death. These findings suggest that the BMPs operate predominantly within multipotent clones to increase neuronal and inhibit oligodendroglial development and that they are not survival or proliferative factors for lineagerestricted neuronal precursors.

\section{High BMP concentrations reduce E16 cortical cell number in both proliferative and differentiating conditions}

To define the effects of higher concentrations of BMP, E16 cortical cells were treated with $100 \mathrm{ng} / \mathrm{ml} \mathrm{BMP} 2$ in either the presence of $10 \mathrm{ng} / \mathrm{ml} \mathrm{FGF} 2$ (to maximally stimulate proliferation) or the absence of FGF2 (to promote neuronal differentiation). This dose of BMP2 dramatically reduced the number of E16 cortical cells in low-density cultures in the presence of FGF2 (Fig. $4 A$ ). The number of viable cells increased between 0 and 8 div in every well containing FGF2 alone, whereas cell numbers actually decreased in $30 \%$ of wells grown with FGF2 plus BMP2 100 $\mathrm{ng} / \mathrm{ml}$. Assessment of viability at $4 \mathrm{div}$ (exclusion of trypan blue) revealed that $83 \pm 4 \%$ of cells were viable in wells containing FGF2, whereas only $42 \pm 4 \%$ were viable in the presence of FGF2 plus BMP2 $(p<0.0001)$. As was seen in E13 cultures, $\mathrm{BMP}$ treatment also reduced proliferation based on serial cell counts (Fig. $4 A$ ) and PCNA expression (at 3 div, FGF2, $84 \pm 4 \%$; FGF2 plus BMP2, $62 \pm 5 \%$; $p=0.018)$. Moreover, the percentage of neurons was increased, and no oligodendrocytes were present after BMP2 cotreatment (data not shown). When E16 cortical cells were grown at moderate density in the absence of FGF2, there was limited proliferation, and, by 4 div, almost all surviving cells had differentiated into neurons. In this context, BMP2 (100 ng/ml) induced the death of immature neurons (Fig. $4 C$ ). Thus, as was seen with E13 cells, high concentrations of BMP2 markedly decreased cell number in both proliferative and differentiating conditions. Again, surviving neurons still displayed enhanced neuritic outgrowth (data not shown).

\section{BMP effects on cell number and neuronal differentiation are temporally dissociable from suppressive effects on oligodendroglial differentiation}

The opposing effects of the BMPs on neuronal and oligodendroglial development could reflect several possible mechanisms. First, the BMPs could influence the fate of a multipotent or bipotent neuronal-oligodendroglial progenitor cell (Williams and Price, 1995), directly promoting neuronal differentiation at the expense of oligodendroglial differentiation. Alternatively, the BMPs could have selective effects on two separate subpopulations of cells: enhanced differentiation of neuronal precursors and decreased survival and/or differentiation of oligodendroglial precursors. To help distinguish between these two possibilities, we performed an additional experiment in which cells were grown at 

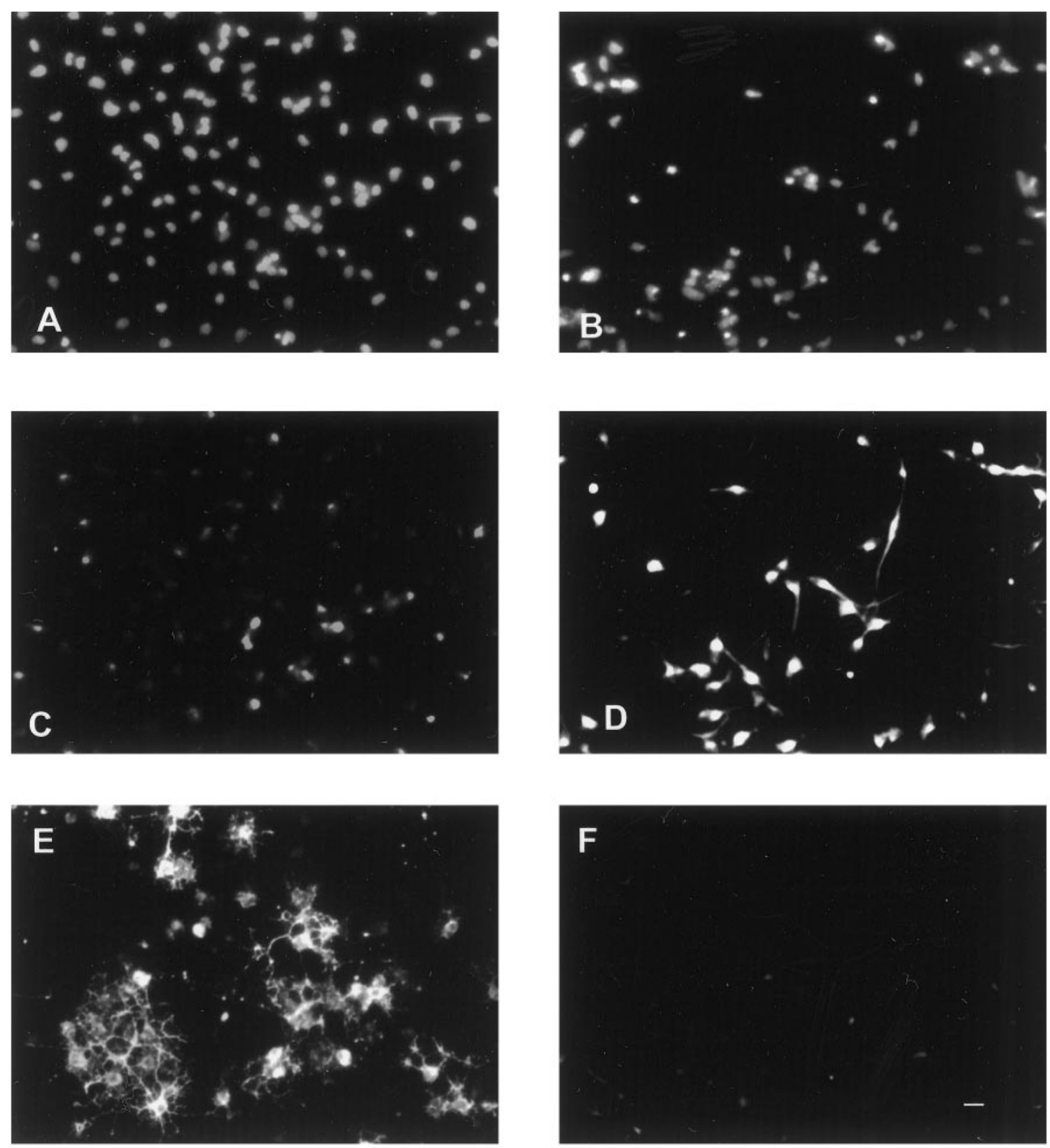

Figure 3. Effects of BMP2 on E16 cortical cells grown at low density with FGF2 $10 \mathrm{ng} / \mathrm{ml}$. Photomicrographs of cells grown with FGF2 alone $(A$, $C$, $E)$ or FGF2 plus BMP2 $10 \mathrm{ng} / \mathrm{ml}(B, D, F)$ for 8 div. $A, B$, Bisbenzimide staining. $C, D, \beta$ tubulin III staining. $E, F$, O4 staining. The same photographic field is shown for each condition. Scale bar, $12 \mu \mathrm{M}$.

low density in FGF2 alone for the first 4 div and then in FGF plus BMP2 (10 and $100 \mathrm{ng} / \mathrm{ml})$ for the subsequent 4 div. Delaying the addition of BMP2 altered its effects on both cell number and phenotype (Fig. 5). Total cell numbers were unaffected rather than dramatically decreased, with delayed addition of BMP2 100 $\mathrm{ng} / \mathrm{ml}$. Neuronal differentiation was somewhat decreased rather than increased by delayed addition of BMP2 at either concentration. Oligodendroglial differentiation, however, was still inhibited after delayed addition of BMP2, and a greater percentage of undifferentiated cells were present (Fig. 5). Thus, the effects of BMP2 on the generation and differentiation of cortical cells changed profoundly over several days, and there was a temporal dissociation between effects of BMP2 on cell number and neu- ronal differentiation (which were lost after delayed addition) versus effects on oligodendroglial differentiation (which persisted). Furthermore, delaying exposure to the BMPs also significantly increased astrocytic differentiation (see below).

\section{BMPs promote astrocytic differentiation}

BMP treatment promoted astrocytic differentiation of both EGFgenerated SVZ progenitor cells and O2A progenitor cells (Gross et al., 1996; Mabie et al., 1997). In the present study, however, few astrocytes were found in low-density E16 cultures, even in the presence of BMP treatment. This raised the question of whether these cells were intrinsically limited in their potential for astrocytic differentiation or, alternatively, whether the combination of 
A

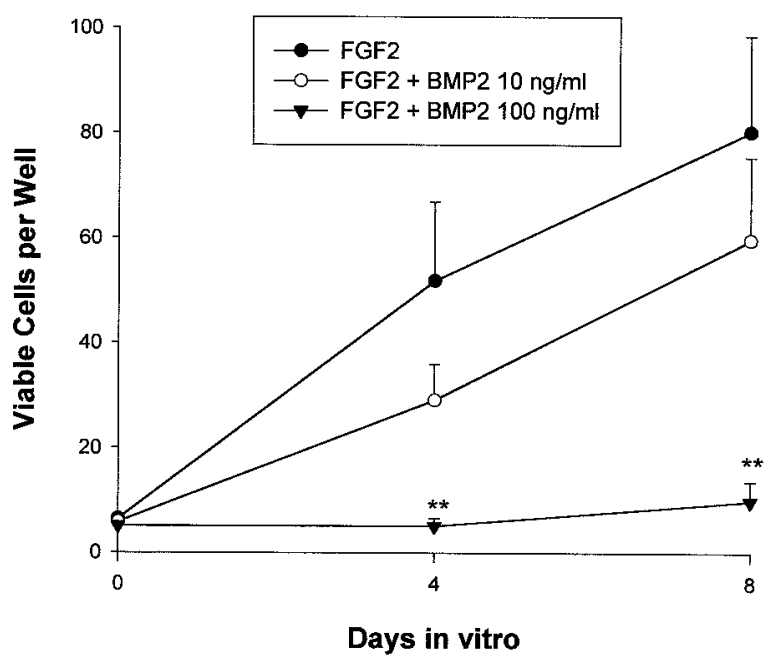

B
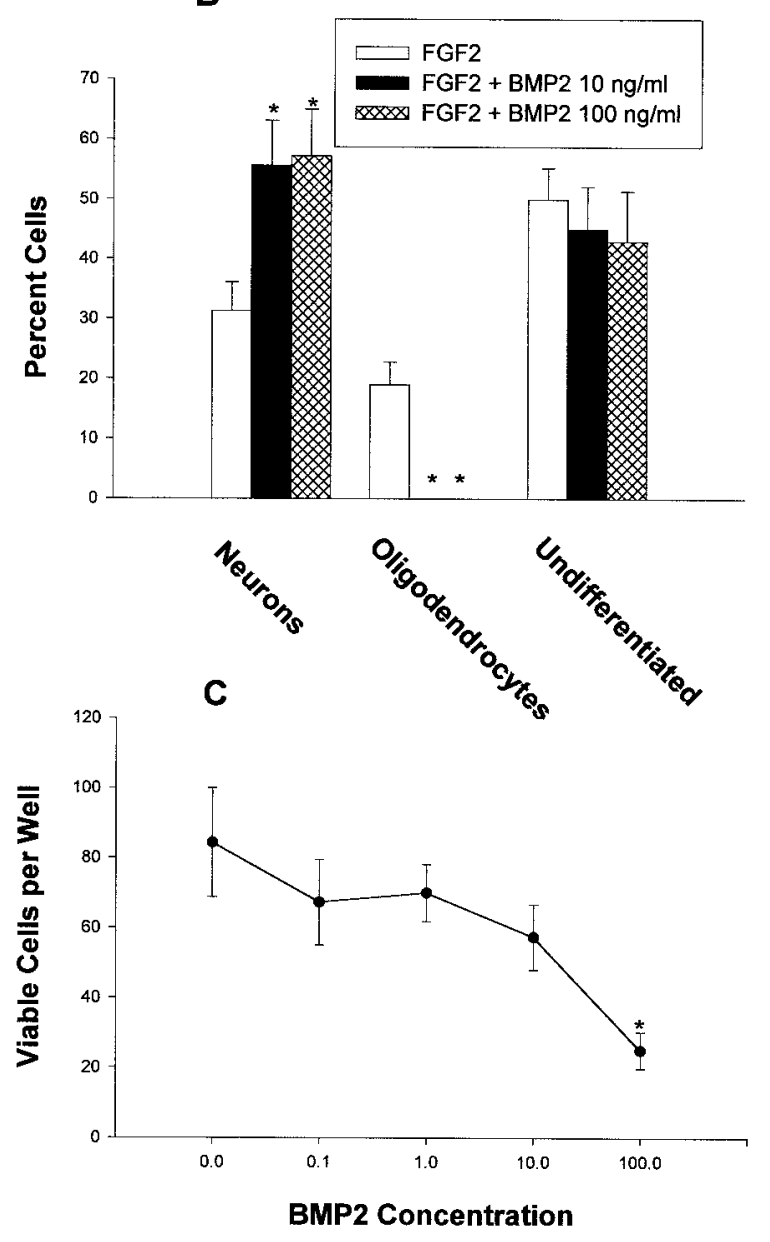

Figure 4. Effects of BMP2 on E16 cortical cells. The number of total viable cells and cells expressing neuronal ( $\beta$ tubulin III), oligodendroglial (O4), and neuroepithelial (nestin) markers was quantitated at the indicated time points. $A$, Effects of BMP2 on E16 cells grown at low density with FGF2 $10 \mathrm{ng} / \mathrm{ml}$. $B$, Effects of BMP2 on the differentiation of E16 cortical grown at low density with FGF2 $10 \mathrm{ng} / \mathrm{ml}$ for 8 div. $C$, Effects of BMP2 $0.1-100 \mathrm{ng} / \mathrm{ml}$ on E16 cortical cells grown at moderate density without FGF2. ${ }^{*} p<0.05 ; * * p<0.01$.
FGF2 plus BMP2 was insufficient to promote astrocytic differentiation at this developmental stage. To examine astrocytic development more fully, two additional experiments were performed. First, as mentioned above, E16 cortical cells were plated at low density in FGF2 alone for 4 div before BMP2 treatment. In addition to the effects described above, delaying the addition of BMP2 significantly increased the number of astrocytes (Fig. 5), suggesting that the responsiveness of early cortical cells to the astrocyte-inductive effects of the BMPs increases as they develop. Second, we examined the effects of FGF2 plus BMP2 cotreatment on E16 cortical cells plated at moderate density. In contrast to low-density cultures, a moderate number of astrocytes developed in moderate-density cultures treated with FGF2 alone for 8 div. In these cultures, BMP cotreatment promoted astrocytic differentiation; astrocytes differentiated more rapidly and constituted a higher percentage of total cells. FGF2-treated cultures contained $8 \pm 2 \%$ astrocytes at $5 \mathrm{div}$ and $35 \pm 3 \%$ astrocytes at $8 \mathrm{div}$. BMP2 $(10 \mathrm{ng} / \mathrm{ml})$ cotreated cultures contained $19 \pm 2 \%$ astrocytes at 5 $\operatorname{div}(p=0.04)$ and $50 \pm 4 \%$ astrocytes at $8 \operatorname{div}(p=0.01)$. Consistent with low-density cultures, the percentages of neurons and oligodendrocytes were increased and decreased, respectively (data not shown). Thus, within a permissive environment, the BMPs promoted astrocytic differentiation of E16 cells.

\section{Noggin, a BMP antagonist, promotes oligodendroglial differentiation and inhibits neuronal differentiation}

In many developmental contexts, BMP signaling is inhibited by endogenous antagonists that limit the availability of ligand to receptors. At least one of these antagonists, noggin, is expressed in the developing cortex (Valenzuela et al., 1995), raising the possibility that intrinsic BMP signaling within the cortex is regulated in this fashion. E16 cortical cells were therefore cultured at low density with FGF2 in the absence or presence of noggin (100 $\mathrm{ng} / \mathrm{ml}$ ). This concentration was chosen based on its ability to block the effect of $10 \mathrm{ng} / \mathrm{ml}$ of BMP2 (data not shown). Noggin cotreatment significantly increased the number of oligodendrocytes without altering the total number of cells (Figs. 6, 7). Noggin also consistently decreased the percentage of neurons that differentiated, although this effect did not reach statistical significance (Figs. 6, 7). This suggests that endogenously produced BMPs may influence the development of cultured cortical cells by inhibiting oligodendroglial differentiation and promoting neuronal differentiation. Furthermore, cell survival and differentiation in the developing cortex may be coordinately regulated by BMP antagonists, as well as by the BMPs themselves.

\section{BMP2 and noggin are expressed in the developing cortex}

Although expression of transcripts for BMP ligands and receptors within the forebrain has been well documented (Furuta et al., 1997; Mehler et al., 1997; Zhang et al., 1998), knowledge of ligand localization is limited. Based on recent immunohistochemical evidence demonstrating BMP2 and/or BMP4 protein along the cortical ventricular lining during the period of neurogenesis ( $\mathrm{Li}$ et al., 1998) and the results of nuclease protection assays (unpublished observations) and in situ hybridizations (Furuta et al., 1997), it seems likely that protein localization is more widespread than the level of transcript detectable by in situ hybridization. In the case of BMP4, one possible explanation for this is the presence of BMP4 transcripts in the presumptive choroid plexus, whereby protein released into the CSF could easily reach cells 


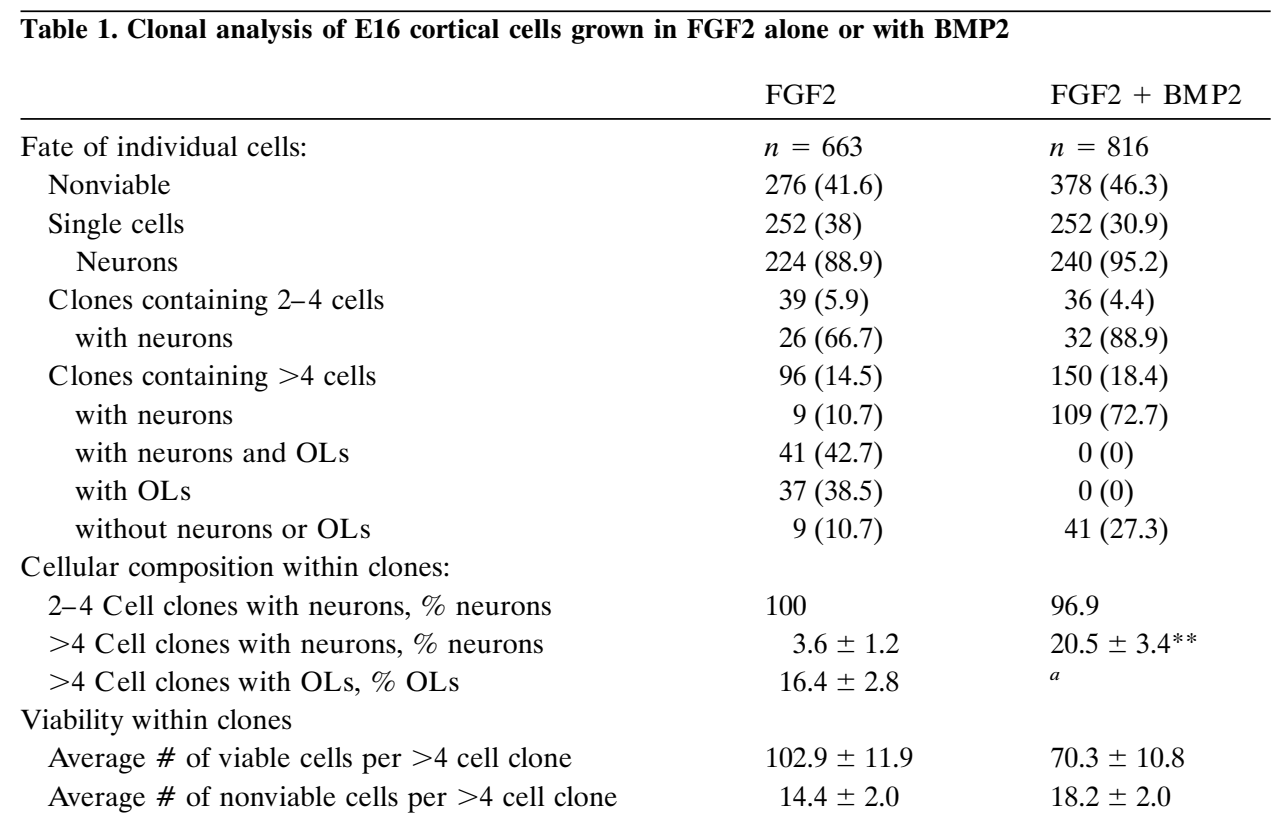

Clonal analysis of E16 cortical cells grown in FGF2 alone or FGF2 plus $1 \mathrm{ng} / \mathrm{ml} \mathrm{BMP2}$. Fate of individual cells, Each absolute value is followed by a percentage in parentheses, which reflects the percentage of all cells in that particular category. Cellular composition within clones, Viability within clones, Each value represents the mean \pm SEM. Neurons and oligodendroglia were identified by $\beta$ tubulin III and $\mathrm{O} 4$ expression, respectively. Cells expressing the astrocytic marker GFAP were not included because they were never seen as single cells or in small clones and were present in $<1 \%$ of clones of more than four cells.

${ }^{a}$ No clones containing oligodendroglia were seen with BMP2 treatment.

${ }^{*} p<0.05 ;{ }^{* *} p<0.01$.

lining the ventricular system. Many BMPs are also highly expressed in the placenta and in endothelial cells and thus at stages of CNS development before the formation of a strict blood-brain barrier, BMPs may enter the CNS from the circulation.

To examine the distribution of BMP2 protein in the developing cortex, embryonic and neonatal brains were analyzed by immunohistochemistry with antibodies to BMP2. In E16 rat brain, BMP2 protein was expressed abundantly throughout the cortex, from the ventricular lining to the pial surface (Fig. $8 A$ ). In the neonatal cortex, BMP2 staining was again prominent in the cortical plate and ependymal/subependymal region but was absent in the developing subcortical white matter/corpus callosum (Fig. $8 B$ ). This pattern of BMP2 protein distribution coincides with the pattern of BMP receptor subunit transcripts at these developmental stages (Zhang et al., 1998).

Because the BMP antagonist noggin is also known to be expressed within the developing cortex (Valenzuela et al., 1995), we also examined its distribution. In agreement with the low level of noggin transcript in the early cortex (Valenzuela et al., 1995), noggin protein was undetectable by immunohistochemistry in E15 mouse cortex (data not shown). In neonatal mice, noggin protein was abundant in the developing subcortical white matter/ corpus callosum and was much less apparent throughout the remainder of the cortex (Fig. $8 C$ ). This suggests that, during the major period of neurogenesis and gliogenesis, BMP2 signaling is most active near the ventricular lining and in the cortical plate. In contrast, in the intermediate zone and developing subcortical white matter, BMP2 signaling is less active because of a decrease in the amount of ligand and an increase in the amount of antagonist. Thus, interactions between BMP2 and noggin may regulate cortical cell development by defining spatial gradients of BMP signaling, similar to what has been postulated in earlier patterning events (Sasai et al., 1995; Wilson and Hemmati-Brivanlou, 1995; Hogan, 1996).

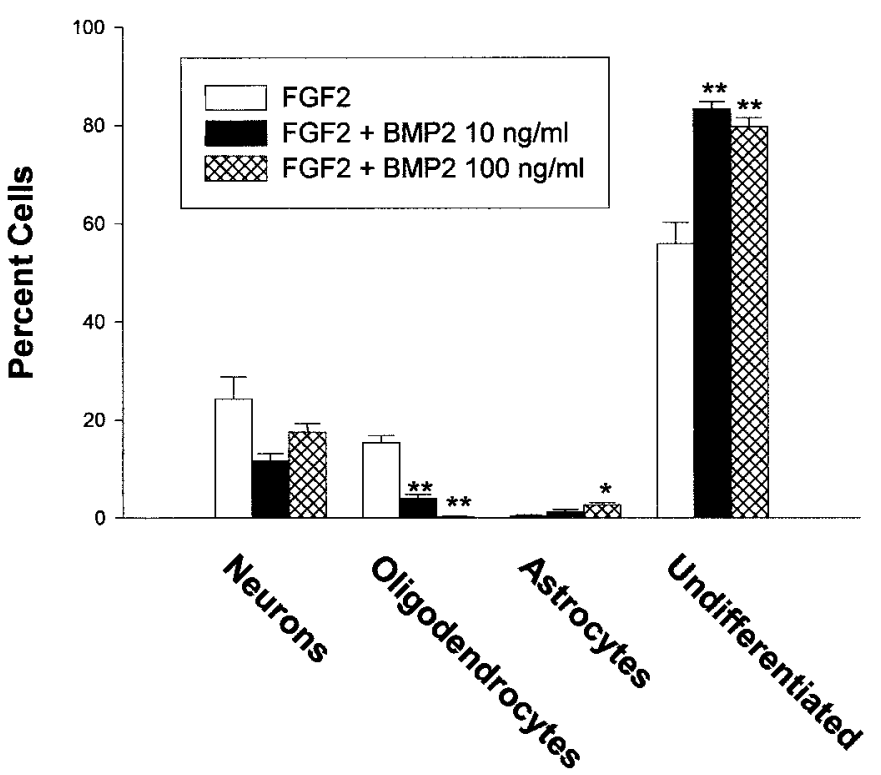

Figure 5. Effects of delaying the addition of BMP2 on E16 cortical cell differentiation. Cells were grown at low density with FGF2 alone for the first 4 div, and then BMP2 was added at 10 or $100 \mathrm{ng} / \mathrm{ml}$. The number of cells expressing neuronal ( $\beta$ tubulin III), oligodendroglial $(\mathrm{O} 4)$, astrocytic (GFAP), and neuroepithelial (nestin) markers was quantitated at 8 div. ${ }^{*} p<0.05 ; * * p<0.01$. 

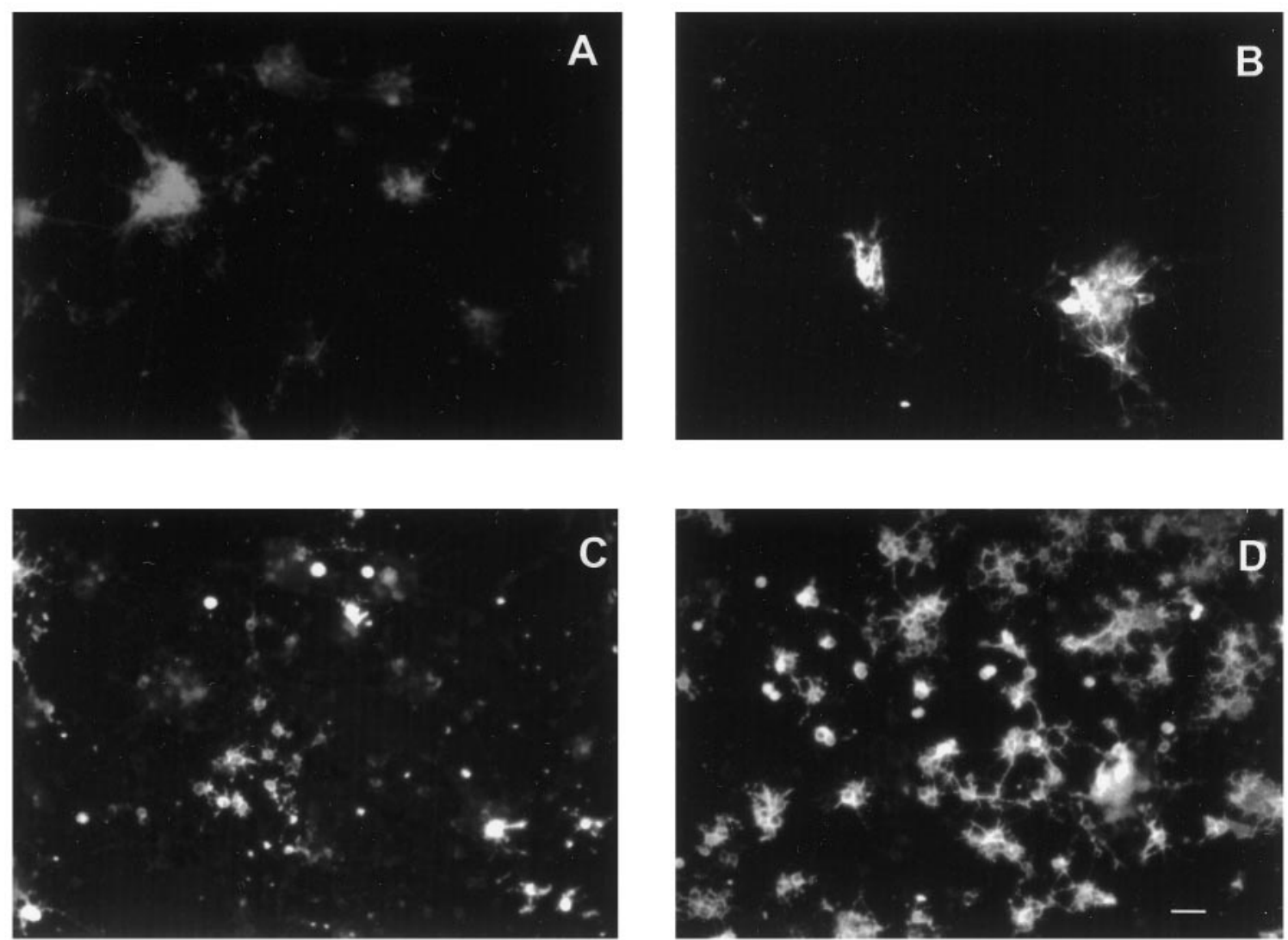

Figure 6. Effects of noggin on E16 cortical cells grown at low density with FGF2 $10 \mathrm{ng} / \mathrm{ml}$. Photomicrographs of cells grown with FGF2 alone $(A, C)$ or FGF2 plus noggin $100 \mathrm{ng} / \mathrm{ml}(B, D)$ for 8 div. $A, B, \beta$ tubulin III staining. $C, D$, O4 staining. Scale bar, $15 \mu \mathrm{M}$.

\section{DISCUSSION}

The BMPs appear to play multiple roles in the regulation of cortical cell fate. Effects of BMP signaling vary depending on the timing of exposure, the dose, and the presence of other environmental signals. Early in cortical development (E13), the predominant effects of BMP signaling are the induction of cell death and the inhibition of proliferation. At E16, moderate doses of the BMPs (1-10 ng/ml) promote neuronal differentiation. Under permissive conditions, and increasingly with time, they induce astrocytic differentiation of older progenitors. Oligodendroglial differentiation is inhibited at all stages. Although these effects suggest complex regulatory mechanisms underlying BMP signaling, similar kinds of sequential actions have been reported for the BMPs in earlier neural development and in other organ systems (Fann and Patterson, 1994; Liem et al., 1995; Lien et al., 1995; Sasai et al., 1995; Wilson and Hemmati-Brivanlou, 1995; Reissmann et al., 1996; Shah et al., 1996; Jernvall et al., 1998; Kalyani et al., 1998; Mujtaba et al., 1998). Our data are consistent with previous reports analyzing the effects of the BMPs on cortical cells (Furuta et al., 1997; Li et al., 1998). By demonstrating how the concentrations of BMPs and mitogenic growth factors (i.e., FGF2) influence the choice between death and differentiation, our study clarifies the apparent contradictory role of the BMPs in promoting cortical apoptosis and neuronal differentiation. Our use of low-density and clonal analysis to follow cell fate over longer culture periods has enabled us to define the effect of BMP signaling on multipotent progenitor cells and to clarify the role of BMP signaling on glial development. Our observations suggest that BMP signaling may be important at multiple stages of neural development and that the biological responses of cortical progenitor cells to the BMPs differ depending on the prevailing developmental context.

\section{BMP induction of cortical cell death}

Although estimates of the proportion of cells undergoing apoptosis during corticogenesis vary widely depending on the method of detection (Finlay and Slattery, 1983; Ferrer et al., 1992; Wood et al., 1992; Blaschke et al., 1996; Takahashi et al., 1996; Furuta et al., 1997; Price et al., 1997), cell death has been increasingly recognized as an important mechanism for the regulation of cell number and phenotype within the developing cortex. In our studies, the cells dying in response to BMP treatment almost always displayed morphological hallmarks of apoptotic cell death, including cell shrinkage, pyknosis, and the formation of membrane-bound nuclear fragments (apoptotic bodies) (Kerr et al., 1995). Although we did not use any biochemical assays for apoptosis, the BMPs have been implicated in apoptosis of other neural (Graham et al., 1994; Glozak and Rogers, 1996; Furuta et al., 1997; Song et al., 1998), as well as mesenchymal (Niswander and Martin, 1993; Zou et al., 1997; Jernvall et al., 1998), cell types. BMP-induced death of cortical progenitor cells was accompanied by an anti-mitotic effect, suggesting that death might result, in part, from the incompatibility of mitotic (FGF2) and anti-mitotic (BMP) signaling (Freeman et al., 1994; Park et al., 1996, 1998). This hypothesis is supported by the increased susceptibility to BMP-induced death after cotreatment with the 


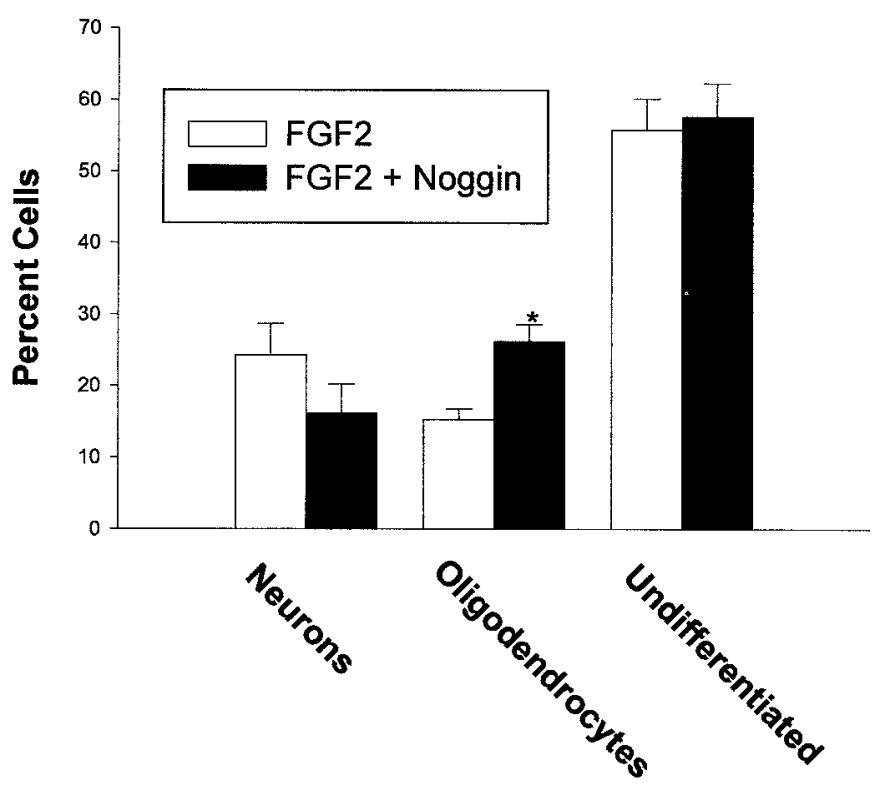

Figure 7. Effects of noggin on E16 cortical cells grown at low density with FGF2 $10 \mathrm{ng} / \mathrm{ml}$. The number of cells expressing neuronal ( $\beta$ tubulin III), oligodendroglial (O4), and neuroepithelial (nestin) markers was quantitated at 8 div. ${ }^{*} p<0.05 ;{ }^{* *} p<0.01$.

mitogen FGF2 and the observation that E13 cortical cells, which proliferate more rapidly than E16 cells, are more sensitive to the death-inductive effect of the BMPs than E16 cells. The increased sensitivity of E13 cells to exogenous BMPs may also reflect a higher level of endogenous BMP signaling at this developmental stage. High concentrations of BMP2 also induced death of postmitotic neurons in the absence of FGF2, indicating that BMPinduced death may occur by mechanisms other than conflicting signaling influences on the cell cycle. Another hypothesis is that the BMPs promote death by inducing premature or inappropriate dependence on other survival factors. For example, treatment of immortalized sympathoadrenal progenitor with BMP2 induces their dependence on exogenous growth factors for survival, and BMP-treated cells undergo apoptosis in the absence of such trophic support (Song et al., 1998). Presumably, the BMPs initiate a cell death program unless it is suppressed by exogenous growth factors.

\section{BMP regulation of cortical cell differentiation}

The effects of the BMPs on neural progenitor cell differentiation in vitro are strikingly dependent on the developmental stage of the cells and the culture conditions. At concentrations lower than those promoting cell death, we found that BMP treatment promoted neuronal differentiation of E16, but not E13, cortical progenitor cells. Our clonal analysis demonstrates that exposure to the BMPs dramatically increases the frequency of clones containing neurons, as well as the proportion of neurons that differentiate within neuron-containing clones, while simultaneously eliminating the generation of oligodendroglia. These findings suggest that the BMPs influence the development of cortical lineages by an instructive mechanism on multipotent cells (increasing the probability of neuronal differentiation and preventing oligodendroglial development within single multipotent clones). The presence of these differentiating effects in microwells containing less than four cells and the high levels of BMP receptors in the cortical ventricular zone (Zhang et al., 1998) suggest that these are direct effects of BMP signaling. The absence of a neuronogenic effect on E16 cells when BMP exposure is delayed for 4 div demonstrates that this effect of exogenous BMP occurs only within a relatively brief developmental window.

The effects of BMPs on E16 cortical progenitors reported here differ dramatically from those observed with cultured EGFgenerated SVZ progenitor cells in which BMP treatment promotes astrocytic differentiation at the expense of neurons and oligodendroglia (Gross et al., 1996). Similarly, BMP treatment of FGF-generated progenitor cells from the perinatal SVZ promotes astrocytic differentiation, inhibits oligodendroglial differentiation, and has no effect on neuronal differentiation (our unpublished observations). Thus, there are differences in progenitor cells from different developmental stages irrespective of the mitogen used to support the cells in culture.

Although few astrocytes were found in low-density E16 cultures, even in the presence of BMP2, treatment with BMP2 significantly increased astrocytic differentiation in higher density cultures, suggesting the need for a cofactor to generate astrocytes at this early developmental stage. However, delaying the addition of BMP2 to E16 cortical cells significantly increased the number of astrocytes, even in low-density cultures, indicating that the responsiveness of early cortical cells to the astrocyte-inductive effects of the BMPs increases as they develop. Previous studies
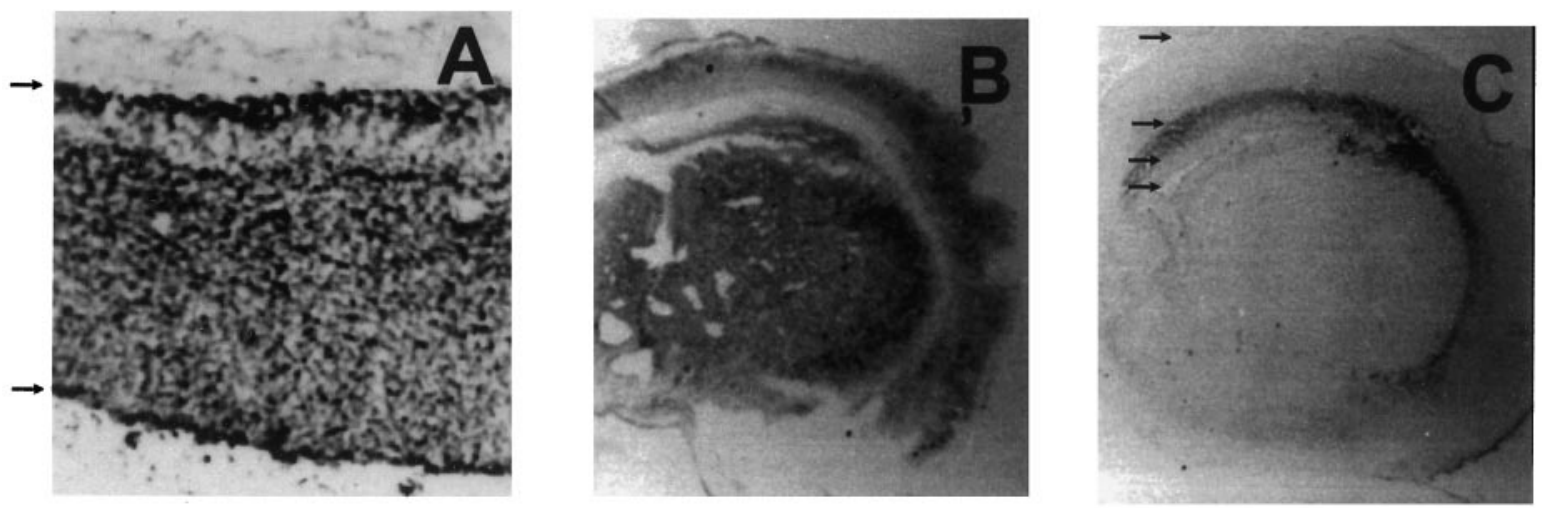

Figure 8. BMP2 and noggin expression in the developing cortex. Photomicrographs of E16 rat $(A)$ and neonatal $(B, C)$ murine cortex stained with a monoclonal antibody to BMP2 $(A, B)$ and a monoclonal antibody to noggin $(C)$. The arrows in $A$ indicate the pial (top) and ventricular (bottom) surfaces. For neonatal coronal sections $(B, C)$, the arrows in $C$ indicate the position of (from top to bottom) the pial surface, the border between cortical gray matter and developing subcortical white matter, the border between subcortical white matter and subventricular zone, and the lateral ventricle. 
have demonstrated that CNTF treatment induces differentiation of embryonic progenitors into GFAP-immunoreactive cells (Johe et al., 1996). Addition of BMP2 along with CNTF further increased the percentage of GFAP-immunoreactive cells (data not shown), indicating that the effects of BMP2 are additive to those of CNTF at E16. BMP2 treatment also induced a more stellate morphology characteristic of astrocytes. Thus, at earlier embryonic stages (e.g., at approximately E16), the BMPs may be involved in enhancing astrocytic differentiation after induction of the phenotype by cofactors such as CNTF. At later stages, BMPs are sufficient to both induce and enhance astrocytic differentiation (Gross et al., 1996; Mabie et al., 1997), even in the absence of CNTF signaling (Koblar et al., 1998). We hypothesize, therefore, that postnatal astrocyte differentiation may primarily reflect BMP signaling. This hypothesis is consistent with previous suggestions that there may be more than one developmental pathway for astrocytic differentiation (Cameron and Rakic, 1991; Koblar et al., 1998; Rajan and McKay, 1998).

A consistent finding in all of our work with BMPs and CNS progenitor cells is the inhibition of oligodendroglial development. This finding is present with both embryonic and postnatal cultures derived from cortex and other regions and occurs independent of whether cells are initially grown in serum or mitogenic growth factors, such as FGF2 or EGF. In light of our previous studies of EGF-generated SVZ cells and O2A cells (Gross et al., 1996; Mabie et al., 1997), the results reported here suggest that the mechanisms underlying this suppressive effect are complex. At early developmental stages (e.g., E13), the predominant mechanism of this suppressive effect is most likely the death of a precursor pool. At later developmental stages (e.g., perinatal) the predominant mechanism is the induction of astroglial differentiation of a bipotent glial progenitor cell at the expense of oligodendroglial differentiation (Mabie et al., 1997). At an intermediate stage (e.g., E16), the data presented here suggests that oligodendroglial inhibition occurs by a block in the differentiation pathway, resulting in the acquisition of the neuronal phenotype and/or the retention of an undifferentiated phenotype.

These results have interesting implications for the study of oligodendrogliogenesis. Several recent studies have demonstrated that, although progenitors competent to differentiate into oligodendrocytes have a widespread distribution in the early CNS, in vivo the earliest oligodendroglial progenitors arise in relatively discrete regions along the ventral neural axis (Cameron-Curry and Le Douarin, 1995; Hardy and Friedrich, 1996; Orentas and Miller, 1996). Over time, oligodendrocytes become more widespread by either migration and/or a process of progressive inductive signaling. In the forebrain, the progeny of bipotent glial progenitors within the SVZ adopt an astrocytic or oligodendroglial fate depending on their postmigratory environment (Levison and Goldman, 1993). We propose that the anatomic restriction of oligodendroglial development is regulated in part by the level of BMP signaling. Support for this hypothesis comes from the loss of ventral neural tube cell types in the noggin knock-out mouse (McMahon et al., 1998). Together, these results suggest that oligodendrocyte development requires inhibition of BMP signaling.

In summary, these findings suggest that the level of BMP signaling, as determined by local concentrations of ligands and antagonists, coordinately regulates cortical cell fate and morphogenesis. Defining the signaling pathways and gene regulatory events that correspond to these effects should help elucidate the intracellular mechanisms of developmental cell death, neurogenesis, and gliogenesis.

\section{REFERENCES}

Altman J, Bayer SA (1995) Atlas of prenatal rat brain development. Boca Raton, FL: CRC.

Beckstead JH (1994) A simple technique for preservation of fixationsensitive antigens in paraffin-embedded tissues. J Histochem Cytochem 42:1127-1134.

Bernier SM, Goltzman D (1992) Effects of protein and steroidal osteotropic agents on differentiation and epidermal growth factor-mediated growth of the CFK1 osseous cell line. J Cell Physiol 152:317-327.

Blaschke AJ, Staley K, Chun J (1996) Widespread programmed cell death in proliferative and postmitotic regions of the fetal cerebral cortex. Development 122:1165-1174.

Cameron RS, Rakic P (1991) Glial cell lineage in the cerebral cortex: a review and synthesis. Glia 4:124-137.

Cameron-Curry P, Le Douarin NM (1995) Oligodendrocyte precursors originate from both the dorsal and the ventral parts of the spinal cord. Neuron 15:1299-1310.

Cho KWY, Blitz IL (1998) BMPs, Smads and metalloproteases: extracellular and intracellular modes of negative regulation. Curr Opin Genet Dev 8:443-449.

Davis AA, Temple S (1994) A self-renewing multipotential stem cell in embryonic rat cerebral cortex. Nature 372:263-266.

Fann MJ, Patterson PH (1994) Depolarization differentially regulates the effects of bone morphogenetic protein (BMP)-2, BMP-6, and activin A on sympathetic neuronal phenotype. J Neurochem 63:2074-2079.

Ferrer I, Soriano E, Del Rio JA, Alcantara S, Auladell C (1992) Cell death and removal in the cerebral cortex during development. Prog Neurobiol 39:1-43.

Finlay BL, Slattery M (1983) Local differences in the amount of early cell death in neocortex predict adult local specializations. Science 219:1349-1351.

Freeman RS, Estus S, Johnson EM (1994) Analysis of cell cycle-related gene expression in postmitotic neurons: selective induction of cyclin D1 during programmed cell death. Neuron 12:343-355.

Furuta Y, Piston DW, Hogan BLM (1997) Bone morphogenetic proteins (BMPs) as regulators of dorsal forebrain development. Development 124:2203-2212.

Ganan Y, Macias D, Duterque-Coquillaud M, Ros MA, Hurle JM (1996) Role of TGF $\beta$ s and BMPs as signals controlling the position of the digits and the areas of interdigital cell death in the developing chick limb autopod. Development 122:2349-2357.

Glozak MA, Rogers MB (1996) Specific induction of apoptosis in P19 embryonal carcinoma cells by retinoic acid and BMP2 or BMP4. Dev Biol 179:458-470.

Graham A, Francis-West P, Brickell P, Lumsden A (1994) The signalling molecule BMP4 mediates apoptosis in the rhombencephalic neural crest. Nature 372:684-686.

Gritti A, Parati EA, Cova L, Frolichsthal P, Galli R, Wanke E, Faravelli L, Morassutti DJ, Roisen F, Nickel DD, Vescovi AL (1996) Multipotential stem cells from the adult mouse brain proliferate and self-renew in response to basic fibroblast growth factor. J Neurosci 16:1091-1100.

Gross RE, Mehler MF, Mabie PC, Zang Z, Santschi L, Kessler JA (1996) Bone morphogenetic proteins promote astroglial lineage commitment by mammalian subventricular zone progenitor cells. Neuron 17:595-606.

Hardy RJ, Friedrich VL (1996) Oligodendrocyte progenitors are generated throughout the embryonic mouse brain, but differentiate in restricted foci. Development 122:2059-2069.

Hogan BLM (1996) Bone morphogenetic proteins: multifunctional regulators of vertebrate development. Genes Dev 10:1580-1594.

Jernvall J, Aberg T, Kettunen P, Keranen S, Thesleff I (1998) The life history of an embryonic signaling center: BMP4 induces p21 and is associated with apoptosis in the mouse tooth enamel knot. Development 125:171-180.

Johe KK, Hazet TG, Muller T, Dugich-Djordjevic MM, McKay RDG (1996) Single factors direct the differentiation of stem cells from the fetal and adult central nervous system. Genes Dev 10:3129-3140.

Kalyani AJ, Piper D, Mujtaba T, Lucero MT, Rao MS (1998) Spinal cord neuronal precursors generate multiple neuronal phenotypes in culture. J Neurosci 18:7856-7868.

Kerr JF, Gobe GC, Winterford CM, Harmon BV (1995) Anatomical 
methods in cell death. In: Methods in cell biology (Schwartz LM, Osborne BA, eds), pp 1-26. New York: Academic.

Kilpatrick TJ, Bartlett PF (1993) Cloning and growth of multipotential neural precursors: requirements for proliferation and differentiation. Neuron 10:255-265.

Kilpatrick TJ, Bartlett PF (1995) Cloned multipotential precursors from the mouse cerebrum require FGF-2, whereas glial restricted precursors are stimulated with either FGF-2 or EGF. J Neurosci 15:3653-3661.

Koblar SA, Turnley AM, Classon BJ, Reid KL, Ware CB, Cheema SS, Murphy M, Bartlett PF (1998) Neural precursor differentiation into astrocytes requires signaling through the leukemia inhibitory factor receptor. Proc Natl Acad Sci USA 95:3178-3181.

Kretzschmar M, Doody J, Massague J (1997) Opposing BMP and EGF signalling pathways converge on the TGF- $\beta$ family mediator Smad-1. Nature 389:618-622.

Levison SW, Goldman JE (1993) Both oligodendrocytes and astrocytes develop from progenitors in the subventricular zone of postnatal rat forebrain. Neuron 10:201-212.

Li W, Cogswell CA, LoTurco JJ (1998) Neuronal differentiation of precursors in the neocortical ventricular zone is triggered by BMP. J Neurosci 18:8853-8862.

Liem KF, Tremmi G, Roelink H, Jessell TM (1995) Dorsal differentiation of neural plate cells induced by BMP-mediated signals from epidermal ectoderm. Cell 82:969-979.

Lien P, Johnson M, Guo X, Rueger D, Higgins D (1995) Osteogenic protein-1 induces dendritic growth in rat sympathetic neurons. Neuron 15:597-605.

Mabie PC, Mehler MF, Marmur R, Papavasiliou A, Song Q, Kessler JA (1997) Bone morphogenetic proteins induce astroglial differentiation of oligodendroglial-astroglial progenitor cells. J Neurosci 17:4112-4120.

McMahon JA, Takada S, Zimmerman LB, Fan CM, Harland RM, McMahon AP (1998) Noggin-mediated antagonism of BMP signaling is required for growth and patterning of the neural tube and somite. Genes Dev 12:1438-1452.

Mehler MF, Mabie PC, Zhang D, Kessler JA (1997) Bone morphogenetic proteins in the nervous system. Trends Neurosci 20:309-317.

Mujtaba T, Mayer-Proschel M, Rao MS (1998) A common neural progenitor for the CNS and PNS. Dev Biol 200:1-15.

Murphy M, Drago J, Bartlett PF (1990) Fibroblast growth factor stimulates the proliferation and differentiation of neural precursor cells in vitro. J Neurosci Res 25:463-475.

Neubuser A, Peters H, Balling R, Martin GR (1997) Antagonistic interactions between FGF and BMP signaling pathways: a mechanism for positioning the sites of tooth formation. Cell 90:247-255.

Niswander L, Martin GR (1993) FGF-4 and BMP-2 have opposite effects on limb growth. Nature 361:68-71.

Orentas DM, Miller RH (1996) The origin of spinal cord oligodendrocytes is dependent on local influences from the notochord. Dev Biol 177:43-53.

Park DS, Farinelli SE, Greene LA (1996) Inhibitors of cyclin-dependent kinases promote survival of post-mitotic neuronally differentiated PC12 cells and sympathetic neurons. J Biol Chem 271:8161-8169.

Park DS, Morris EJ, Stefanis L, Troy CM, Shelanski ML, Geller HM, Greene LA (1998) Multiple pathways of neuronal death induced by DNA-damaging agents, NGF deprivation, and oxidative stress. J Neurosci 18:830-840.
Price DJ, Aslam S, Tasker L, Gillies K (1997) Fates of the earliest generated cells in the developing murine neocortex. J Comp Neurol 377:414-422.

Qian X, Davis AA, Goderie SK, Temple S (1997) FGF2 concentration regulates the generation of neurons and glia from multipotent cortical stem cells. Neuron 18:81-93.

Rajan P, McKay RD (1998) Multiple routes to astrocytic differentiation in the CNS. J Neurosci 18:3620-3629.

Reissmann E, Ernsberger U, Francis-West PH, Rugeger D, Brickell PM, Rohrer H (1996) Involvement of bone morphogenetic protein-4 and bone morphogenetic protein-7 in the differentiation of the adrenergic phenotype in developing sympathetic neurons. Development 122:2079-2088.

Reynolds BA, Weiss S (1992) Generation of neurons and astrocytes from isolated cells of the adult mammalian central nervous system. Science 255:1707-1710.

Reynolds BA, Tetzlaff W, Weiss S (1992) A multipotent EGFresponsive striatal embryonic progenitor cell produces neurons and astrocytes. J Neurosci 12:4565-4574.

Sasai Y, Lu B, Steinbeisser H, DeRobertis EM (1995) Regulation of neural induction by the Chd and Bmp-4 antagonistic patterning signals in Xenopus. Nature 376:333-336.

Shah NM, Groves AK, Anderson DJ (1996) Alternate neural crest cell fates are instructively promoted by TGF $\beta$ superfamily members. Cell 85:331-343

Song Q, Mehler MF, Kessler JA (1998) Bone morphogenetic proteins induce apoptosis and growth factor dependence of cultured sympathoadrenal progenitor cells. Dev Biol 196:119-127.

Stemple DL, Mahanthappa NK (1997) Neural stem cells are blasting off. Neuron 18:1-4.

Takahashi T, Nowakowski RS, Caviness VS (1996a) Interkinetic and migratory behavior of a cohort of neocortical neurons arising in the early embryonic murine cerebral wall. J Neurosci 16:5762-5776.

Takahashi T, Nowakowski RS, Caviness VS (1996b) The leaving or Q fraction of the murine cerebral proliferative epithelium: a general model of neocortical neuronogenesis. J Neurosci 16:6183-6196.

Valenzuela DM, Economides AN, Rojas E, Lamb TM, Nunez L, Jones P, Ip NY, Espinosa R, Brannan CI, Gilbert DJ, Copeland NG, Jenkins NA, LeBeau MM, Harland RM, Yancopoulos GD (1995) Identification of mammalian noggin and its expression in the adult nervous system. J Neurosci 15:6077-6084.

Williams BP, Price J (1995) Evidence for multiple precursor cell types in the embryonic rat cerebral cortex. Neuron 14:1181-1188.

Wilson PA, Hemmati-Brivanlou A (1995) Induction of epidermis and inhibition of neural fate by Bmp-4. Nature 376:331-333.

Wood JG, Martin S, Price DJ (1992) Evidence that the earliest generated cells of the murine cerebral cortex form a transient population in the subplate and marginal zone. Brain Res Dev Brain Res 66:137-140.

Zhang D, Mehler MF, Song Q, Kessler JA (1998) Development of bone morphogenetic protein receptors in the nervous system and possible roles in regulating trkC expression. J Neurosci 18:3314-3326.

Zou H, Wieser R, Massague J, Niswander L (1997) Distinct roles of type I bone morphogenetic protein receptors in the formation and differentiation of cartilage. Genes Dev 1:2191-2203. 